${ }^{1}$ ДВНЗ «Тернопільський державний медичний університет імені І. Я. Горбачевського МОЗ України»

${ }^{2}$ Луцький національний технічний університет

\title{
ЗАСТОСУВАННЯ СОМSOL MULTIPHYSICS ДЛЯ МАТЕМАТИЧНОГО МОДЕЛЮВАННЯ ВИВЧЕННЯ ПРОЦЕСУ РОЗПАДУ ДНК У ПЛАЗМІ
}

\author{
D. V. Vakulenko' ${ }^{1}$, O. M. Kuchvara ${ }^{1}$, A. V. Semenets ${ }^{1}$, I. Ye. Andrushchak ${ }^{2}$ \\ ${ }^{1}$ I. Horbachevsky Ternopil State Medical University \\ ${ }^{2}$ Lutsk National Technical University

\section{APPLICATION OF COMSOL MULTIPHYSICS FOR MATHEMATICAL MODELING OF THE STUDY OF THE PROCESS OF DNA BREAKDOWN IN PLASMA}

\begin{abstract}
Анотація. Використання сучасних комп’ютерних технологій у процесі викладання курсу комп’ютерного моделювання у фармації сприяє формуванню вмінь та навичок в умовах невпинного розвитку комп’ютеризації та впровадженню математичного моделювання у фармації. Зокрема, у статті розглянуто переваги та недоліки застосування математичного моделювання за допомогою COMSOL Multiphysics у формуванні компетентності майбутніх фармацевтів.

Розглянуто ступінь ефективності, зручності та доступності застосування програмного середовища COMSOL Multiphysics в курсі комп’ютерного моделювання у фармації для студентів 3-го курсу фармацевтичного факультету на прикладі вивчення процесу розпаду ДНК у плазмі.

Використання сучасних комп’ютерних продуктів у процесі викладання комп’ютерних технологій у фармації сприяє формуванню вмінь та навичок із математичного моделювання у фармації, зокрема, генна терапія - один із прикладів біотехнології клінічного застосування. Вирішення головної проблеми - доставки генів, пов’язаних із транспортуванням плазмідної ДНК (пДНК) до мішеней, та перетворення між різними формами пДНК, використання функції оцінки параметрів за допомогою інженерії та реакцій інтерфейсу, для пошуку констант швидкості трьох послідовних реакцій, що беруть участь у ДНК процесі деградації.
\end{abstract}

Ключові слова: COMSOL Multiphysics; математичне моделювання у фармації.

Abstract. The use of modern computer technology in the course of teaching computer modeling in pharmacy contributes to the formation of skills and competencies in the conditions of continuous development of computerization and implementation of mathematical modeling in pharmacy. In particular, the article discusses the advantages and disadvantages of using mathematical modeling using COMSOL Multiphysics to shape the competencies of future pharmacists.

The degree of efficiency, convenience and accessibility of the COMSOL Multiphysics software environment in computer modeling in pharmacy for students of the 3rd year of study of the Faculty of Pharmacy on the example of studying the process of DNA decay in plasma is considered.

The use of modern computer products in the teaching of computer technology in pharmacy contributes to the development of mathematical modeling skills in pharmacy, in particular, gene therapy is one example of clinical biotechnology. Solution to the main problem - delivery of genes related to the transport of plasmid DNA (pDNA) to targets and conversion between different forms of pDNA, the use of parameter estimation by engineering and interface reactions, to find the rate constants of three consecutive reactions involved in the DNA process degradation.

Key words: COMSOL Multiphysics; mathematical modeling in pharmacy.

(ㄱ Д. В. Вакуленко, О. М. Кучвара, А. В. Семенець, І. Є. Андрущак 
Вступ. Числове моделювання фізичних процесів $€$ важливим етапом проектування фармакокінетичних процесів. Оскільки багато фізичних законів формулюється за допомогою диференціальних рівнянь у частинних похідних (ДРЧП), то для їх дослідження потрібен універсальний інструмент, який, крім іншого, здатний поєднувати різні хімічні та фізичні моделі. COMSOL Multiphysics [1, 6, 8] - це потужне програмне середовище, яке створене для моделювання фізичних процесів і здатне розв’язувати широкий спектр наукових хіміко-біологічних задач із багатьох медичних та фармацевтичних напрямків. При розв’язанні ДРЧП у системі здебільшого використовується метод скінченних елементів (МСкЕ). Система має налаштовані інтерфейси (прикладні режими) для розв'язання задач з різноманітних сфер, таких, як механіка, електромагнетизм, гідродинаміка, хімія, акустика, теплопровідність, дифузія, оптика, опір матеріалів, теорія пружності тощо.

Генна терапія - один із прикладів біотехнології клінічного застосування. Головна проблема - доставка генів, пов'язаних із транспортуванням плазмідної ДНК (пДНК) до мішеней, та перетворення між різними формами пДНК. У цьому прикладі використовується функція оцінки параметрів за допомогою інженерії, реакцій інтерфейсу для пошуку констант швидкості трьох послідовних реакцій, що беруть участь у ДНК процесі деградації.

Мета статті - розглянути ступінь ефективності, зручності та доступності застосування програмного середовища COMSOL Multiphysics в курсі комп'ютерного моделювання у фармації для студентів 3-го курсу фармацевтичного факультету на прикладі вивчення процесу розпаду ДНК у плазмі.

Теоретична частина. Дослідження базуються на аналізі пДНК, які використовуються для експресії білків в організмі людини, білків, які можуть мати терапевтичний вплив [8]. пДНК існує у таких трьох формах, як перекрита форма (SC), відкрита-кругова форма (OC) та лінійна форма (L) - кожна із різною швидкістю експресії білка. Ці форми пДНК перетворюються та деградують 3 часом, що означає терапію пацієнта. Швидкість експресії білка для форми SC $є$ більшою, ніж для форми OC, яка, у свою чергу, значно більша, ніж для форми L.

Кінетична модель у цьому дослідженні передбачає, що пДНК-форми взаємоперетворюються та розкладаються за механізмом, наведеним на рис. 1 . Модель вважається однонаправленим процесом.
SC, OC та L лінійний представляють кількість перекритої, відкритої круглої та лінійної плазміди відповідно у кожному відділенні. Константи швидкості $\mathrm{k}_{1}, \mathrm{k}_{2} \mathrm{i} \mathrm{k}_{3}$ являють собою константи деградації для перекритої, відкритої кругової та лінійної плазмід відповідно.

$$
S C \stackrel{k_{1}}{\longrightarrow} \text { OC } \stackrel{k_{2}}{\longrightarrow} L \stackrel{k_{3}}{\longrightarrow} F
$$

Рис. 1. Кінетична модель деградації плазмідної ДНК у плазмі крові.

Цей приклад пропонує набір незворотних реакцій, у яких пДНК у формі SC перетворюється до форми OC, а потім до форми L. Тоді L-форма розкладається на ряд лінійних фрагментів, спільно позначених як F. Три незворотні реакції на рис. 1 перетворюють у ці вирази швидкості реакції:

$$
\begin{aligned}
& r_{1}=k_{1} c_{S C} \\
& r_{2}=k_{2} c_{O C} \\
& r_{3}=k_{3} c_{L}
\end{aligned}
$$

Константи швидкості $\mathrm{k}_{1}$ до $\mathrm{k}_{3}$ були отримані [8] шляхом оцінки параметрів, використовуючи значення експериментальних даних, які подано у таблиці 1.

Таблиця 1. Експериментальні дані

\begin{tabular}{|c|c|c|c|}
\hline TIME $(\mathrm{s})$ & $\mathrm{C}_{\mathrm{SC}}(\mathrm{ng} / \mu \mathrm{l})$ & $\mathrm{c}_{\mathrm{OC}}(\mathrm{ng} / \mu \mathrm{l})$ & $\mathrm{c}_{\mathrm{L}}(\mathrm{ng} / \mu \mathrm{l})$ \\
\hline 5 & 9,3 & 0,5 & 0 \\
\hline 60 & 5,0 & 4,1 & 0,1 \\
\hline 120 & 3,5 & 6,5 & 0,3 \\
\hline 180 & 1,1 & 7,0 & 0,5 \\
\hline 300 & 0,5 & 8,1 & 0,8 \\
\hline 420 & 0,1 & 8,0 & 1,2 \\
\hline 600 & 0 & 7,8 & 1,7 \\
\hline 900 & 0 & 7,1 & 2,4 \\
\hline 1200 & 0 & 6,3 & 2,5 \\
\hline 1800 & 0 & 4,5 & 2,6 \\
\hline 2400 & 0 & 3,0 & 2,0 \\
\hline 3000 & 0 & 2,1 & 1,8 \\
\hline 3600 & 0 & 1,5 & 1,2 \\
\hline
\end{tabular}

Наступні константи швидкості обчислюються з експериментальних даних та пропонується механізм реакції: $\mathrm{k}_{1}=9,6 \times 10^{-3}(1 / \mathrm{c}), \mathrm{k}_{2}=4,8 \times 10^{-4}$ (1/c) i $\mathrm{k}_{3}=9,6 \times 10^{-4}$ (1/c). Крім того, початкова концентрація видів SC оцінюється до 9,7 нг/мкл. На рис. 2 показані експериментальні значення в тому ж графіку, що і результати моделювання. Зрозуміло, припущення кінетичної моделі узгоджуються 3 експериментальними висновками.

Розрахункові константи швидкості показують, що переохолоджена пДНК швидко перетворюється на 


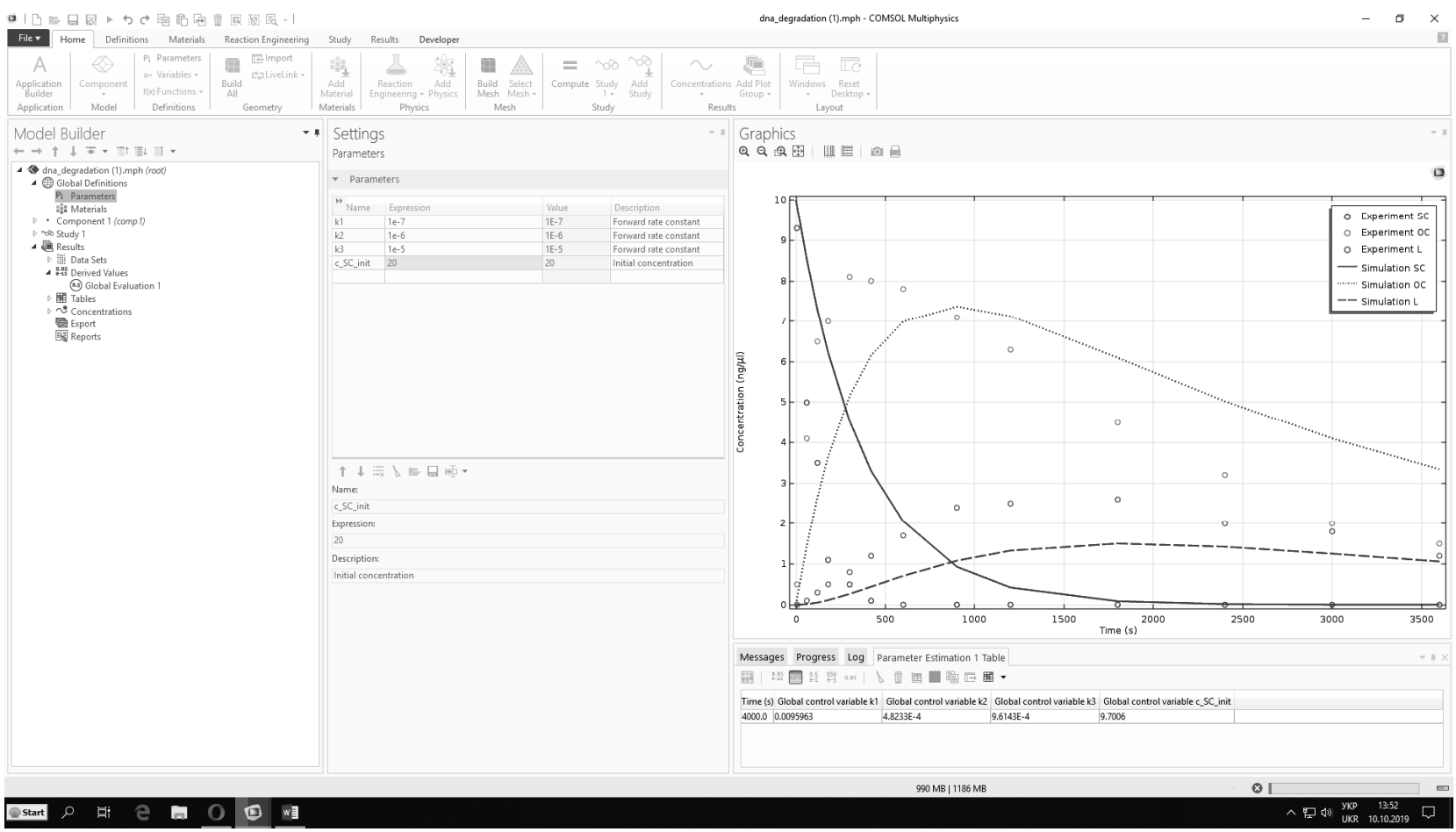

Рис. 2. Скріншот інтерфейсу побудованої моделі вивчення процесу розпаду ДНК у плазмі.

відкриту круглу форму з періодом напіввиведення приблизно 1,2 хвилини:

$$
t_{1 / 2}=\frac{\ln 2}{k}
$$

Відкритий круговий та лінійний розпад пДНК із періодом напіврозпаду 24,1 та 12,0 хвилин відповідно. Як згадувалося, переохолоджена пДНК має найвищу швидкість експресії білка 3 трьох форм. Однак, оскільки форма SC має період напіввиведення всього 1,2 хвилини, це $є$ ймовірно, що він розкладається під час транспортування до терапевтичних мішеней [10]. Отже, з цього випливає, що ми повинні знайти способи перешкодити відносно швидкому розпаду SC.

Висновки та перспективи подальших досліджень. Використання сучасних комп'ютерних продуктів у процесі викладання комп'ютерних технологій у фармації сприяє формуванню вмінь та навичок із математичного моделювання у фармації [9], зокрема, генна терапія - один із прикладів біотехнології клінічного застосування. Вирішення головної проблеми - доставки генів, пов’язаних із транспортуванням плазмідної ДНК (пДНК) до мішеней, та перетворення між різними формами пДНК, використання функції оцінки параметрів за допомогою інженерії та реакцій інтерфейсу, для пошуку констант швидкості трьох послідовних реакцій, що беруть участь у ДНК процесі деградації. Перспективами даного дослідження $є$ більш широке використання $[3,4]$ та вивчення математичних моделей $[1,2]$ на основі диференціальних рівнянь [5] у частинних похідних у курсі комп’ютерного моделювання у фармації для більш якіснішої підготовки майбутніх фармацевтів до їх професійної діяльності.

\section{Список літератури}

1. Введення до Comsol Multiphysics [Електронний pecypc]. - Режим доступу : http://cdn.comsol.com/ docs/5.4/IntroductionToCOMSOLMultiphysicsRU54.pdf.

2. Жулкевич I. В. Персоналізація в онкології: індивідуальний підхід до профілактики тромбоемболічних ускладнень при пангістеректомії / I. В. Жулкевич, Б. Д. Кривокульський // Вісник соці-

альної гігієни та організації охорони здоров'я України. - 2018. - № 4 (78). - С. 11-18.

3. Марценюк В. П. Концептуальные подходы к интегрированной среде проведения научных медикобиологических исследований / В. П. Марценюк, А. В. Семенец, А. С. Сверстюк // Штучний інтелект. 2003. - № 2. - C. 35-43. 
4. Марценюк В. П. Математичні теорії та алгоритми для моделювання реконструкції кісткової тканини / В. П. Марценюк, О. Л. Ковальчук, І. В. Жулкевич // Проблеми остеопорозу / за ред. проф. Л. Я. Ковальчука. Тернопіль : Укрмедкнига, 2002. - С. 78-94.

5. Марценюк В. П. Про нелінійну динамічну систему реконструкції кісткової тканини / В. П. Марценюк, І. В. Жулкевич, О. Я. Ковальчук // Вісник Київського університету. Сер. «Фізико-математичні науки». - 2001. № 4. - С. 292-298.

6. Математическое моделирование физико-химических процессов в среде Comsol Multiphysics 5.2 / А. В. Коваленко, А. М. Узденова, М. Х. Уртенов, В. В. Никоненко. - СПб. : Лань, 2017. - 228 с.

7. Самарський А. А. Математичне моделювання: ідеї, методи, приклади [Електронний ресурс] / А. А. Самарський. - М. : Физматгиз, 2002. - Режим доступу :

\section{References}

1. Vvedenia v Comsol Multiphysics [Introduction to Comsol Multiphysics]. Retrieved from: http://cdn.comsol.com/ docs/5.4/IntroductionToCOMSOLMultiphysicsRU54.pdf [in Ukrainian].

2. Zhulkevych, I.V., \& Kryvokulskyi, B.D. (2018). Personalizatsiia $\mathrm{v}$ onkolohii: indyvidualnyi pidkhid do profilaktyky tromboembolichnykh uskladnen pry panhisterektomii [Personalization in oncology: individual approach to the prevention of thromboembolic complications during hysterectomy]. Visnyk sotsialnoi hihiieny ta orhanizatsii okhorony zdorovia Ukrainy - Bulletin of Social Hygiene and Health Care Organization of Ukraine, 4 (78), 11-18 [in Ukrainian].

3. Martsenyuk, V.P., Semenets, A.V., \& Sverstyuk, A.S. (2003). Kontseptualnye podkhody k integrirovannoy srede provedeniya nauchnykh medyko-biologicheskykh issledovaniy [Conceptual approaches to an integrated environment for scientific and biological research]. Shtuchnyy intelekt - Artificial Intelligence, 2, 35-43 [in Russian].

4. Martsenyuk, V.P., Kovalchuk, O.L., \& Zhulkevych, I.V. (2002). Matematychni teorii ta alhorytmy dlia modelyuvannia rekonstruktsiii kistkovoi tkanyny. Problemy osteoporozu [Mathematical Theories and Algorithms for Simulation of Bone Tissue Reconstruction. Problems of Osteoporosis]. Kovalchuk, L.Ya. (Ed.). Ternopil: Ukrmedknyha (pp. 7894) [in Ukrainian].

5. Martseniuk, V.P., Zhulkevych, I.V., \& Kovalchuk, O.Ya. (2001). Pro neliniinu dynamichnu systemu rekonstruktsii kistkovoi tkanyny [On nonlinear dynamical system of bone
http://www.immsp.kiev.ua/postgraduate/Biblioteka_trudy/ MatemModelirovSamarskij2001.pdf.

8. Houk B. E. Kinetic modeling of plasmid DNA degradation in rat plasma / B. E. Houk, G. Hochhaus, J. A. Hughes // AAPS Pharmsci. - 1999. - Vol. 1, No. 3. P. 15-20.

9. HPLC method development for the analysis of Bisoprolol in combined dosage form containing Bisoprolol and Enalapril and in vitro dissolution studied / L. Logoyda, S. Kovalenko, A. M. AbdelMegied [et al.] // International Journal of Applied Pharmaceutics. - 2019. - Vol. 11 (3). - P. 186194. DOI: https://doi.org/10.22159/ijap.2019v11i3.32391.

10. Wilkes J. O. Fluid mechanics for chemical engineers with microfluidics, CFD, and COMSOL multiphysics 5 / Prentice hall international series in the physical and chemical engineering sciences / J. O. Wilkes // Prentice Hall. 2017. -3 edition. - P. 816.

tissue reconstruction]. Visnyk Kyivskoho universytetu. Ser. Fizyko-matematychni nauky - Bulletin of the University of Kyiv. Avg. Physical and Mathematical Sciences, 4, 292-298 [in Ukrainian].

6. Kovalenko, A.V., Uzdenova, A.M., Urtenov, M.Kh., \& Nikonenko, V.V. (2017). Matematicheskoye modelirovaniye fiziko-khimicheskikh protsesov v srede Comsol Multiphysics 5.2 [Mathematical modeling of physicochemical processes in a medium Comsol Multiphysics 5.2]. [in Russian].

7. Samarskyi, A.A. (2002). Matematychne modeliuvannia: idei, metody, pryklady [Mathematical modeling: idea, methody, apply]. Moscow: Fizmatgiz. Retrieved from: http:// www.immsp.kiev.ua/postgraduate/Biblioteka_trudy/MatemModelirovSamarskij2001.pdf [in Ukrainian].

8. Houk, B.E., Hochhaus, G., \& Hughes, J.A. (1999). Kinetic modeling of plasmid DNA degradation in rat plasma. AAPS Pharmsci, 1, 3, 15-20.

9. Logoyda, L., Kovalenko, S., AbdelMegied, A.M., Zhulkevych, I., Drapak, I., Demchuk, I., \& Netsyuk, O. (2019). HPLC method development for the analysis of bisoprolol in combined dosage form containing Bisoprolol and Enalapril and in vitro dissolution studied. International Journal of Applied Pharmaceutics, 11 (3), 186-194. DOI: https:// doi.org/10.22159/ijap.2019v11i3.32391.

10. Wilkes, J.O. (2017). Fluid mechanics for chemical engineers with microfluidics, CFD, and COMSOL multiphysics 5 / Prentice hall international series in the physical and chemical engineering sciences (the 3-th edn.). Prentice Hall. 